ReVISTA de BIOLOGía TROPICAL

\title{
Reproductive phenology of epiphytes in Monteverde, Costa Rica
}

\author{
Kimberly S. Sheldon ${ }^{1 *} \&$ Nalini M. Nadkarni ${ }^{2}$ \\ 1. Department of Zoology and Physiology, 1000 East University Avenue - Dept. 3166, University of Wyoming, Laramie, \\ WY 82071, USA; kimberlyssheldon@gmail.com \\ 2. Department of Biology, 257 South 1400 East, University of Utah, Salt Lake City, UT 84112, USA; \\ nalini.nadkarni@utah.edu \\ * Correspondence
}

Received 20-X-2014. Corrected 03-V-2015. Accepted 01-VI-2015.

\begin{abstract}
Phenology of plants, or the timing of life cycle events, is important for understanding plant ecology, forest dynamics, and plant-animal interactions. In tropical forests, studies that document epiphyte reproductive phenology are relatively few because of the challenges of tracking plants that live in the canopy. Phenological patterns for 279 individuals of 7 epiphyte species were examined across 12 months in a tropical montane forest in Monteverde, Costa Rica. Epiphytes were located in one of two common tree species, Ficus tuerckheimii (Moraceae) or Ocotea tonduzii (Lauraceae). Flowering and fruiting (i.e., when ripe or unripe fruit is present on the plant) of study plants was recorded on monthly intervals, and phenology was examined as a function of the season at the study site (i.e., wet, transition, or dry season), and pollinator syndrome (bird-, or insect-pollinated) and seed dispersal syndrome (bird-, bat-, or wind-dispersed) of each plant. Though some epiphyte species flowered and fruited throughout the year, the majority showed significant seasonality in phenological events. Based on circular statistics, the timing of mean flowering of different epiphyte species varied, however, timing of mean fruiting for most species tended to occur during the wet season. Insect- and bird-pollinated species had peak flowering during the dry season and late wet season, respectively. Bird-dispersed fruits were present each month of the year with peaks from February to October and again in December. Wind-dispersed fruits were observed eight months of the year with a peak in the early wet season. The timing of epiphyte flowering coincided with flowering of large trees in the area. Epiphyte fruiting, however, is distinct from large tree fruiting. Our results demonstrate the seasonal nature of flowering and fruiting in individual epiphyte species while also highlighted the asynchronous nature of phenological events amongst the epiphyte community. Rev. Biol. Trop. 63 (4): 11191126. Epub 2015 December 01.
\end{abstract}

Key words: arboreal plants, biodiversity, cloud forest, Neotropical, phenological patterns, reproductive biology, tropical canopy.

Phenology, or the timing of life cycle events, is of critical importance for plants. Understanding when phenological events occur and the environmental cues underlying these processes are becoming increasingly important as global change alters climate patterns throughout the world. Plants in temperate forests (Tooke \& Battey, 2010) and seasonally dry tropical forests (Janzen, 1967; McLaren \& McDonald, 2005) tend to have a single, synchronous reproductive cycle each year due to seasonal constraints of temperature and moisture (Ting, Hartley, \& Burns, 2008). In wet tropical environments, where annual temperature shows little fluctuation and dry periods are less pronounced, plant phenology may respond to subtle environmental cues, such as small shifts in light, nutrients or precipitation (Van Schaik, Terborgh, \& Wright,1993; Morellato, Talora, Takahashi, Bencke, \& Zipparo, 2000; Zimmerman, Wright, Calderón, Aponte Pagán, \& Pat, 2007; Günter et al., 2008).

Phenological studies in tropical regions have typically examined flowering and 
fruiting in trees or understory shrubs (Gentry \& Emmons, 1987, Van Schaik et al., 1993; Newstrom, Frankie, \& Baker, 1994; Morellato et al., 2000). Far less is known about patterns of epiphyte phenology in the canopy (Hietz, 1997). Previous studies have examined reproductive ecology (e.g. Canela \& Sazima, 2003a,b; Kamke, Schmid, Zillikens, Lopes, \& Steiner, 2011) and phenology of individual epiphyte species (García-Franco \& Rico-Gray, 1991; Flores-Palacios \& García-Franco, 2003), with the vast majority of work focused on phenology of species in the plant Families Bromeliaceae and Orchidaceae (Sahagun-Godinez, 1996; Lasso \& Ackerman, 2003; Hietz, Winkler, Cruz-Paredes, \& Jimenez-Aguilar, 2006; Ramírez-Morillo, González, Chi, Carnevali, \& May, 2008; Orozco-Ibarrola, Flores-Hernández, Victoriano-Romero, Corona-López, \& Flores-Palacios, 2015). Epiphytes in tropical canopies are, however, remarkably diverse and likely show asynchronous phenological patterns at the community level. Because epiphytes are key players in primary productivity, carbon sequestration, water and nutrient cycling, and mutualistic interactions with pollinating and seed-dispersing animals (Ackerman 1986; Clark, Nadkarni, Schaefer, \& Gholz, 1998; Diaz, Sieving, Peña-Foxon, Larrain, \& Armesto, 2010), studies on epiphytes are an important addition to our understanding of tropical forest processes.

Our goal was to understand patterns of flower and fruit production of epiphytes representing several plant Families in a tropical montane cloud forest across months and seasons of the year. Because the production of flowers and fruits when appropriate pollinators and seed dispersers are present can increase reproductive success and plant fitness (Wenny \& Levey, 1998; Talavera, Bastida, Ortiz, \& Arista, 2001; Elzinga et al., 2007), we also examined phenological patterns in relation to pollinator and seed dispersal syndromes of flowers and fruits, respectively.

\section{MATERIALS AND METHODS}

Study site: Our study was conducted at three sites on the Pacific slope of the Cordillera de Tilarán near Monteverde, Costa Rica; the Estación Biológica $\left(10^{\circ} 19^{\prime} 00^{\prime \prime} \mathrm{N}-84^{\circ} 48^{\prime} 00^{\prime \prime}\right.$ $\mathrm{W} ; 1570 \mathrm{~m}$ in elevation), the Monteverde Cloud Forest Preserve (MCFP) ( 10 $20^{\prime} 00^{\prime \prime}$ $\mathrm{N}-84^{\circ} 45^{\prime} 00^{\prime \prime} \mathrm{W} ; 1494 \mathrm{~m}$ in elevation), and a forest near the Selvatura Canopy Tours $\left(10^{\circ} 20^{\prime} 00^{\prime \prime} \mathrm{N}-84^{\circ} 47^{\prime} 00^{\prime \prime} \mathrm{W} ; 1634 \mathrm{~m}\right.$ in elevation). All sites were located on the same slope aspect, at similar elevations, and within $3 \mathrm{~km}$ from the Estación site.

In Monteverde, three distinct seasons are delimited by changes in rainfall: the wet, transition, and dry seasons. The wet season, from May to October, generally has clear skies in the morning, rainfall during the afternoon, and a mean monthly precipitation of $>250$ $\mathrm{mm}$. The transition, or misty-windy season, from November to January, is characterized by strong winds with mist during the day and night. The dry season, from February to April, has moderate winds and a mean monthly precipitation of $<50 \mathrm{~mm}$ (Clark, Nadkarni, Schaefer, \& Gholz, 1998; Clark et al., 2000). Mean annual temperature is $19^{\circ} \mathrm{C}$ for Monteverde.

We tracked the reproductive seasonality of seven epiphytic species that were abundant at our sites and that represented several plant Families. Individual epiphytes were located on mature trees of two common species at our sites, Ocotea tonduzii Standl. and Ficus tuerckheimii Standl. We chose individual trees of O. tonduzii $(\mathrm{N}=12)$ and F. tuerckheimii $(\mathrm{N}$ $=11$ ) based on size (diameter at breast height of 60-120 cm), height (23-24 m), and our ability to safely climb into the branches to track epiphytes (see Nadkarni, 1988 for climbing methods). The 23 trees used for sampling epiphytes occurred in primary forest plots within the three study sites.

We used flagging at the base of epiphyte stems to tag target plants on each tree. We recorded if individual epiphytes were flowering 
or fruiting at monthly intervals (i.e recorded if flowers or fruits were present). We collected data from tagged epiphytes at all sites from October 2000-September 2001, however, at the Selvatura and Estación we could not collect data in November 2000 and January 2001 due to logistical constraints. We used the Monteverde plant list (Haber, 2000, updated 2008) and the Tropicos Project database from the Missouri Botanical Garden (http://www. tropicos.org/) to determine pollinator syndrome (bird-, or insect-pollinated) and seed dispersal syndrome (bird-, bat-, or wind-dispersed) of each plant. Voucher specimens of epiphytes were stored in the Monteverde Cloud Forest Reserve Herbarium in Monteverde, Costa Rica.

We pooled flowering and fruiting data from the three study sites given their proximity to one another and comparable site features (same slope aspect and similar elevation). Because our data correspond to a one-year cycle (Morellato, Alberti, \& Hudson, 2010), we used circular statistics to examine mean timing of phenological events (Zar, 1999). Our response variable was the proportion of plants that were flowering or fruiting each month for a given species. We converted months to angles with $30^{\circ}$ separating months such that January, February, .... December corresponded to the angles $15^{\circ}, 45^{\circ}, \ldots 345^{\circ}$. We used a Rayleigh test of uniformity ('circular' package, $\mathrm{R}$ Development Core Team, 2010) to determine mean angle (i.e., the month that represents the average of the reproductive event). Prior to the Rayleigh test, we examined circular histograms to verify that the distribution was unimodal (Morellato et al., 2010). When species distributions appeared multimodal (i.e. flowering, $\mathrm{Cav}$ endishia capitulata Smith; fruiting, Psychotria maxonii Standl. and Psychotria pithecobia Standl.), we could not use circular statistics and we assumed no seasonality in phenology. When the Rayleigh test is significant, the mean angle indicates seasonality in the phenological event being examined. We converted mean angle to a corresponding mean date and presented results as "peak" timing of flowering or fruiting. We also determined length of mean vector, $r$, which measures the concentration of the phenological events around the mean angle. Values of $r$ closer to 1 indicate greater concentration of phenological activity around a single date or time (Morellato et al., 2000).

\section{RESULTS}

We tracked flowering and fruiting of 279 individual plants of 7 epiphyte species (Table 1). For Psychotria maxonii, we were unable to collect data in January. Thus, our analyses of flowering and fruiting for $P$. maxonii do not include information for this month. Flowering varied greatly by species (Fig. 1). Four of the seven species we tracked flowered during each season (Cavendishia capitulata, Clusia stenophylla Standl., Guzmania nicaraguensis Mez \& Baker, P. pithecobia). Two species had peak flowering during the wet season (Table 1; Cavendishia melastomoides Klotzsch) and $P$. pithecobia; Rayleigh test: $\mathrm{P} \leq 0.001)$ and two had peak flowering during the dry season (Oreopanax oerstedianus Marchal and P. maxonii; $\mathrm{P}$ $<0.001)$. One species showed peak flowering during the transition season ( $G$. nicaraguensis; $\mathrm{P} \leq 0.03)$. Clusia stenophylla did not show a significant peak in flowering time $(\mathrm{P}=0.12)$.

Three of the seven species we tracked had fruits during each season, however, the peak for fruiting in most species was observed during the wet season (Fig. 2; Table 1). Oreopanax oerstedianus was the only plant that showed peak fruiting during the late dry season, which preceeded the wet season $(\mathrm{P}<0.001)$. The remaining four species with unimodal fruiting patterns (C. capitulata, C. melastomoides, C. stenophylla, G. nicaraguensis) had peak fruiting during the wet season $(\mathrm{P} \leq 0.001)$.

Four species we tracked were insect-pollinated (54\% of all individual plants) and three species were bird-pollinated (46\% of all individual plants). Insect-pollinated species had peak flowering during the dry season $(r=$ $0.36, \mathrm{P}<0.001)$ and bird-pollinated species had peak flowering in the late wet season $(r=0.33$, $\mathrm{P}<0.001)$. 

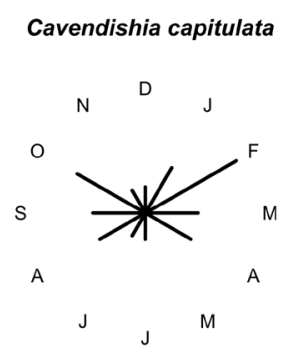

Oreopanax oerstedianus

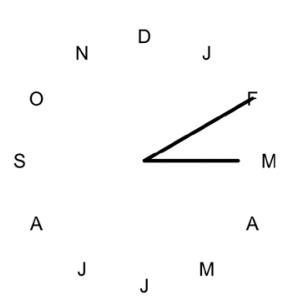

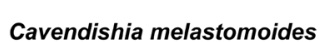

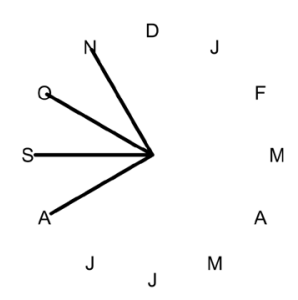

Psychotria maxonii

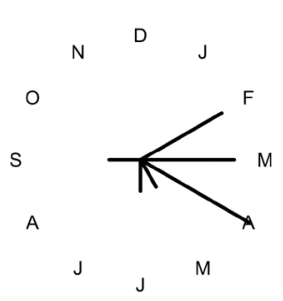

Clusia stenophylla

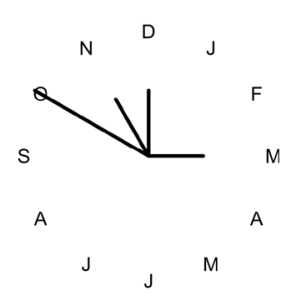

Guzmania nicaraguensis

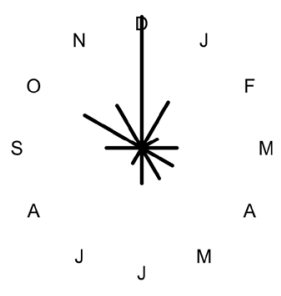

Fig. 1. Circular histograms of flowering periods for seven epiphyte species over a 14-month period. Bars show percentage of individual plants in flower for every month of the year.

Six species we tracked had fruits that were bird-dispersed $(66 \%$ of all individual plants), and the remaining species, G. nicaraguensis, was wind-dispersed (34\% of all individual plants). Bird-dispersed fruits were present each month of the year with peaks from February to October and again in December. Wind-dispersed fruits of G. nicaraguensis were observed eight months of the year with a peak in the early wet season $(r=0.47, \mathrm{P}<0.001)$.

\section{DISCUSSION}

The epiphyte species we studied flowered and fruited throughout the year. The majority of species showed significant seasonality in phenological events, however, phenological events were asynchronous among the epiphyte species. Previous work on trees in Costa Rica showed a similar pattern, with diverse phenological events even among closely related species resulting in asynchronous patterns at the community level (SanMartin-Gajardo \& Morellato, 2003; Boyle \& Bronstein, 2012).
Epiphytes with significant seasonality in flowering showed peaks in the dry season or the late wet season. This showed some similarity to large trees in Monteverde, which show peak flowering in the late dry to early wet seasons (Koptur, Haber, Frankie, \& Baker, 1988; Haber, 2000). Greater flowering activity during the dry season is common in a variety of tropical habitats (Janzen, 1967; Daubenmire, 1972; Frankie, Baker, \& Opler, 1974; van Dulmen, 2001; De Medeiros, Lopes, \& Zickel, 2007) and is believed to be a mechanism that maximizes use of pollinator presence (Janzen, 1967, Talavera et al., 2001).

In contrast, timing of fruit production appears markedly different in epiphytes and large trees in Monteverde. We found that levels of fruiting were highest for epiphyte species during the late dry season $(\mathrm{N}=1)$, early wet season $(\mathrm{N}=3)$, or the late wet season $(\mathrm{N}=1)$. Conversely, large trees had peak fruiting from the late wet to transition season (Koptur et al., 1988; Haber, 2000). Differences in fruiting phenology of epiphytes and trees is corroborated 


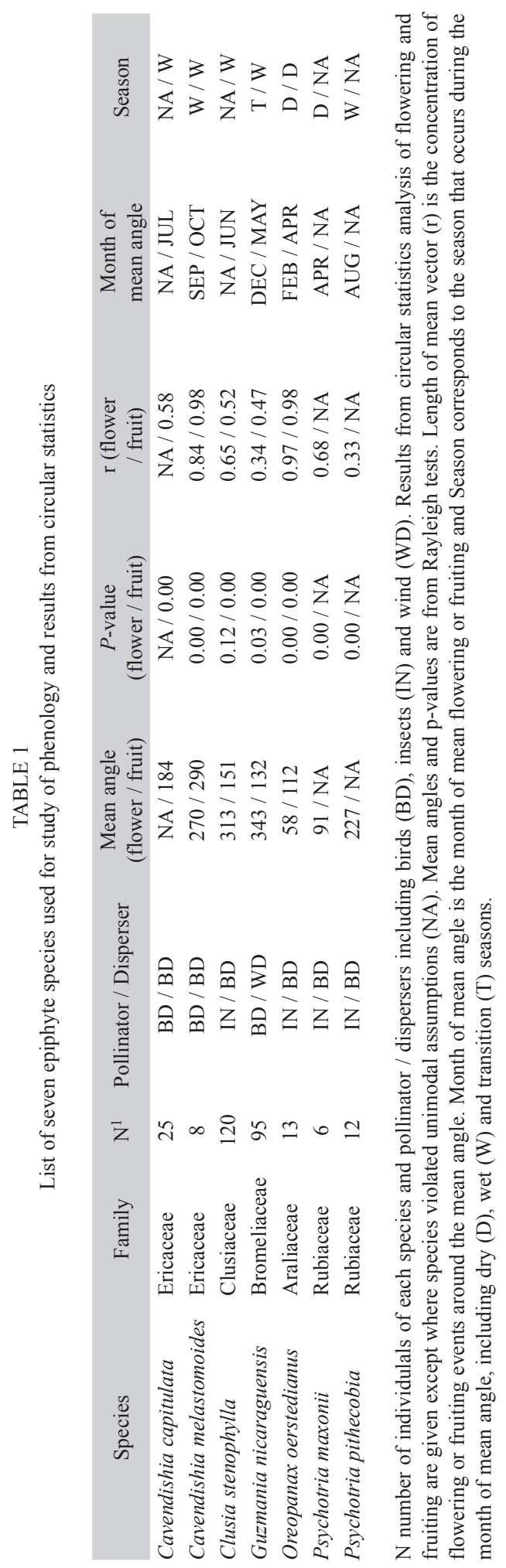

by seed rain patterns in Monteverde: a greater number of seeds from epiphytes landed in seed traps during the dry and wet seasons, whereas a greater number of seeds of non-epiphytic species landed in seed traps during the transition and dry seasons (Sheldon \& Nadkarni, 2013).

Variation in flowering and fruiting among epiphyte species may be driven by the presence of effective pollinators and seed dispersers, which can increase plant reproductive success and fitness (Wenny \& Levey, 1998; Talavera et al. 2001). Frugivorous and nectivorous birds in Monteverde have two altitudinal migration periods; one at the beginning of the wet season when they arrive from lower elevations to the breeding grounds, and one in the late wet season when they descend to the lowlands after breeding (Lawton \& Guindon, 1981; Wheelwright, 1983; Loiselle \& Blake, 1991; Levey \& Stiles, 1992). These movements are believed to be largely a response to food supply (Loiselle \& Blake, 1991; Levey \& Stiles, 1992). In our study, we found that bird-pollinated flowers peaked in the late wet season, but were less abundant during the late dry and early wet season when birds breed in Monteverde. This may be due to the fact that nectivorous birds tend to feed more on insects during the breeding season compared with the non-breeding season (Hardesty, 2009). In contrast, insectpollinated flowers were highest during the dry season. Data are lacking on insect seasonality in Monteverde, thus we do not know if insect pollinators are most abundant and/or effective during this time.

Bird-dispersed fruits of epiphytes were common throughout the year, particularly from the dry through wet season with another peak in the middle of the transition season. Thus, fruit abundance appears highest throughout the time birds are breeding in the wet season and during the time birds are accumulating fat reserves after the breeding season (Loiselle \& Blake, 1991).

Tropical plants rely on seasonal shifts in environmental cues, such as precipitation, to initiate reproductive events (Van Schaik et al., 1993; Morellato et al., 2000). Changes in 


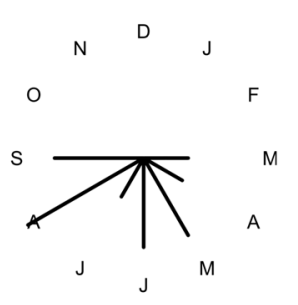

Oreopanax oerstedianus

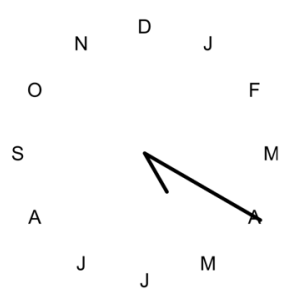

Psychotria maxonii

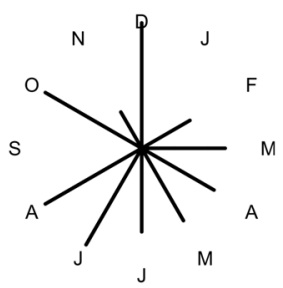

Psychotria pithecobia

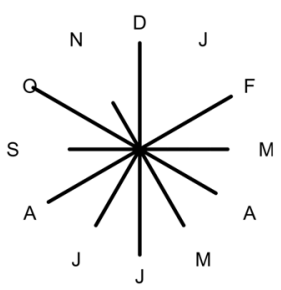

Fig. 2. Circular histograms of fruiting periods for seven epiphyte species over a 14-month period. Bars show percentage of individual plants in fruit for every month of the year.

regional climate in the Cordillera de Tilarán, particularly an increase in the frequency of dry days (Pounds, Fogden, \& Campbell, 1999), may impact the timing of flowering and fruiting and could result in potential mismatches among plants and their pollinators and seed dispersers (Schweiger, Settele, Kudrna, Klotz, \& Kühn, 2008). More extensive sampling across multiple years is needed to better understand the mechanisms underlying flowering and fruiting in epiphytic plants and the consequences of changes in regional climate for plant-animal interactions.

\section{ACKNOWLEDGMENTS}

We thank R. Solano and W. Haber for field assistance and plant identification. We thank the MCFP, Estación Biológica, and Selvatura Canopy Tours for allowing us access to forests and for providing permits and logistical support. We thank K.C. Burns for helpful comments on earlier drafts. Funding for this work came from the University of Utah Department of Biology and research grants from the National Science Foundation (DEB 05-42130 and DEB 09-56301).

\section{RESUMEN}

Fenología reproductiva de epífitas en Monteverde, Costa Rica. La fenología de las plantas, o el cronograma de eventos en el ciclo de vida, es importante para la comprensión de la ecología vegetal, la dinámica de los bosques y de las interacciones planta-animal. En los bosques tropicales, los estudios que documentan la fenología de las epífitas son relativamente pocos debido a los desafíos que representa darles seguimiento a las plantas que viven en el dosel. Aquí se presenta un reporte de los patrones fenológicos de 279 individuos de 7 especies de epífitas que abarca 12 meses en un bosque montano tropical en Monteverde, Costa Rica. Las epífitas se encuentran en una de las dos especies de árboles comunes, Ficus tuerckheimii (Moraceae) u Ocotea tonduzii (Lauraceae). Se registró la floración y fructificación (i.e. cuando la fruta madura o inmadura está presente en la planta) de las plantas de estudio en intervalos mensuales y examinó la fenología a través de las estaciones en el sitio de estudio (i.e. estación húmeda, transición, o seca) y el síndrome de polinizadores 
(ave-, o insecto-polinización ) y el síndrome de dispersión de semillas (ave-, murciélago-, o viento- dispersión) de cada planta. Aunque la mayoría de las especies de epífitas tuvieron flores y frutos durante todo el año, la mayoría mostró estacionalidad significativa en los eventos fenológicos. Con base en estadísticas circulares, el tiempo de floración promedio de las especies de epífitas es variado, sin embargo, el momento de la fructificación promedio para la mayoría de las especies tiende a ocurrir durante la estación húmeda. Especies de insectos y aves de polinización tenían pico de floración durante la estación seca y la estación lluviosa tarde, respectivamente. Frutas dispersadas por aves estaban presentes todos los meses del año con picos de febrero a octubre y de nuevo en diciembre. Frutas dispersadas por el viento se observaron ocho meses del año con un pico en la temporada de lluvias temprana. El momento de la floración de las epífitas coincidió con la floración de árboles de gran tamaño en la zona. La fructificación de las epífitas, sin embargo, fue diferente de la fructificación de los árboles de gran tamaño. Nuestros resultados ponen de manifiesto el carácter estacional de la floración y fructificación de las especies epífitas individuales, además de destacar el carácter asincrónico de los eventos fenológicos entre toda la comunidad de epífitas.

Palabras clave: plantas arbóreas, biodiversidad, Costa Rica, bosque nuboso, patrones fenológicos, biología reproductiva, dosel tropical.

\section{REFERENCES}

Boyle, W. A., \& Bronstein, J. L. 2012. Phenology of tropical understory trees: patterns andcorrelates. Revista de Biologia Tropical, 60, 1415-1430.

Canela, M. B. F., \& Sazima, M. (2003a). Aechmea pectinata: a hummingbird-dependend Bromeliad with inconspicouos flowers from the rainforest in SouthEastern Brazil. Annals of Botany, 92, 731-737.

Canela, M. B. F., \& Sazima, M. (2003b). Florivory by the crab Armases angustipes (Grapsidae) influences hummingbird visits to Aechmea pectinata (Bromeliaceae). Biotropica, 35, 289-294.

Clark, K. L., Lawton, R. O., \& Butler, P. R. (2000). The physical environment. In N. M. Nadkarni \& N. T. Wheelwright (Eds.). Monteverde: ecology and conservation (pp. 15-38). New York: Oxford University Press.

Clark, K. L., Nadkarni, N. M., Schaefer, D., \& Gholz, H. L. (1998). Atmospheric deposition and net retention of ions by the canopy in a tropical montane forest, Monteverde, Costa Rica. Journal of Tropical Ecology, 14, 27-45.

Daubenmire, R. (1972). Phenology and other characteristics of tropical semi-deciduous forest in NorthWestern Costa Rica. Journal of Ecology, 60, 147-70.
De Medeiros, D. P. W., Lopes, A. V., \& Zickel, C. S. (2007). Phenology of woody species in tropical coastal vegetation, northeastern Brazil. Flora, 202, 513-520.

Diaz, I. A., Sieving, K. E., Peña-Foxon, M. E., Larrain, J., \& Armesto, J. J. (2010). Epiphyte diversity and biomass loads of canopy emergent trees in Chilean temperate rain forests: a neglected functional component. Forest Ecology and Management, 259, 1490-1501.

Elzinga, J. A., Atlan, A., Biere, A., Gigord, L., Weis, A. E., \& Bernasconi, G. (2007). Time after time: flowering phenology and biotic interaction. Trends in Ecology and Evolution, 22, 432-439.

Flores-Palacios, A., \& García-Franco, J. G. (2003). Effects of floral display and plant abundance on fruit production of Ryncholaelia glauca (Orchidaceae). Revista de Biología Tropical, 51, 71-78.

Frankie, G. W., Baker, H. G., \& Opler, P. A. (1974). Comparative phenological studies of trees in tropical wet and dry forests in the lowlands of Costa Rica. Journal of Ecology, 62, 881-919.

García-Franco, J. G., \& Rico-Gray, V. (1991). Biología reproductiva de Tillandsia deppeana Steudel (Bromeliaceae) en Veracruz, México. Brenesia, 35, 61-79.

Gentry, A. H., \& Emmons, L. H. (1987). Geographical variation in fertility, phenology, and composition of the understory of neotropical forests. Biotropica, 19, 216-227.

Günter, S., Stimm, B., Cabrera, M., Diaz, M. L., Lojan. M., Ordoñez, E., Richter, M., \& Weber, M. (2008). Tree phenology in montane forests of southern Ecuador can be explained by precipitation, radiation and photoperiodic control. Journal of Tropical Ecology, 24, 247-258.

Haber, W. A. (2000). Plants. In N. M. Nadkarni, \& N. T. Wheelwright (Eds.). Monteverde: ecology and conservation (pp. 39-94). New York: Oxford University Press.

Hardesty, J. L. (2009). Using nitrogen-15 to examine protein sources in hummingbird diets. Ornitologia Colombiana, 8, 19-28.

Hietz, P. (1997). Population dynamics of epiphytes in a Mexican humid montane forest. Journal of Ecology, $85,767-775$.

Hietz, P., Winkler, M., Cruz-Paredes, L., \& JimenezAguilar, A. (2006). Breeding systems, fruit set, and flowering phenology of epiphytic bromeliads and orchids in a Mexican humid montane forest. Selbyana, 27, 156-164.

Janzen, D. H. (1967). Synchronization of sexual reproduction of trees within the dry season in Central America. Evolution, 21, 620-37.

Kamke, R., Schmid, S., Zillikens, A., Lopes, B. C., \& Steiner, J. (2011). The importance of bees as pollinators in the short corolla bromeliad Aechmea caudata in southern Brazil. Flora, 206, 746-756. 
Koptur, S., Haber, W. A., Frankie, G. W., \& Baker, H. G. (1988). Phenological studies of shrub and treelet species in tropical cloud forests of Costa Rica. Journal of Tropical Ecology, 4, 323-346.

Lasso, E., \& Ackerman, J. D. (2003). Flowering phenology of Werauhia sintenisii, a bromeliad from the dwarf montane forest in Puerto Rico: an indicator of climate change? Selbyana, 24, 95-104.

Lawton, M. F., \& Guindon, C. F. (1981). Flock composition, breeding success and learning in the Brown Jay. Condor, 83, 27-33.

Levey, D. J., \& Stiles, F. G. (1992). Evolutionary precursors of long-distance migration: resource availability and movement patterns in neotropical landbirds. American Naturalist, 140, 447-476.

Loiselle, B. A., \& Blake, J. G.. (1991). Temporal variation in birds and fruits along an elevational gradient in Costa Rica. Ecology, 72, 180-193.

McLaren, K. P., \& McDonald, M. A. (2005). Seasonal patterns of flowering and fruiting in a dry tropical forest in Jamaica. Biotropica, 37, 584-590.

Morellato, L. P. C., Alberti, L. F., \& Hudson, I. L. (2010). Applications of circular statistics in plant phenology: a case studies approach. In I. L. Hudson, \& M. R. Keatley (Eds.). Phenological research: methods for environmental and climate change analysis (pp. $357-$ 371). New York: Springer.

Morellato, L. P. C., Talora, D. C., Takahashi, A., Bencke, C. C., \& Zipparo, V. B. (2000). A new phenology of Atlantic rain forest trees: a comparative study. Biotropica, 32, 811-823.

Nadkarni, N. M. 1988. Use of a portable platform for observation of animal behavior in tropical tree canopies. Biotropica, 20, 350-51.

Newstrom, L. E., Frankie, G. W., \& Baker, H. G. (1994). A new classification for plant phenology based on flowering patterns in lowland tropical rain forest trees at La Selva, Costa Rica. Biotropica, 26, 141-159.

Orozco-Ibarrola, O. A., Flores-Hernández, P. S., Victoriano-Romero, E., Corona-López, A. M., \& Flores-Palacios, A. (2015). Are breeding system and florivory associated with the abundance of Tillandsia species (Bromeliaceae)? Botanical Journal of the Linnean Society, 177, 50-65.

Pounds, J. A., Fogden, M. P. L., \& Campbell, J. H. (1999). Biological response to climate change on a tropical mountain. Nature, 398, 611-615.

Ramírez-Morillo, I. M., González, J. U., Chi, F., Carnevali, G., \& May, F. (2008). Reproductive biology of six species of Tillandsia L. (Bromeliaceae) in Mexico. Journal of the Bromeliad Society, 58, 149-155.

Sahagun-Godinez, E. (1996). Trends in the phenology of flowering in the Orchidaceae of Western Mexico. Biotropica, 28, 130-136.

SanMartin-Gajardo, I., \& Morellato, L. P. C. (2003). Inter and intraspecific variation on reproductive phenology of the Brazilian Atlantic forest Rubiaceae: ecology and phylogenetic constraints. Revista de Biología Tropical, 51, 691-698.

Schweiger, O., Settele, J., Kudrna, O., Klotz, S., \& Kühn, I. (2008). Climate change can cause spatial mismatch of trophically interacting species. Ecology, 89, 3472-3479.

Sheldon, K. S., \& Nadkarni, N. M. 2013. Spatial and temporal variation of seed rain in the canopy and on the ground of a tropical cloud forest. Biotropica, 45: 549-556.

Talavera, S., Bastida, F., Ortiz, P. L., \& Arista, M. (2001). Pollinator attendance and reproductive success in Cistus libanotis L. (Cistaceae). International Journal of Plant Sciences, 162, 343-352.

Ting, S., Hartley, S., \& Burns, K. C. (2008). Global patterns in fruiting seasons. Global Ecology and Biogeography, 17, 648-657.

Tooke, F., \& Battey, N. H. (2010). Temperate flowering phenology. Journal of Experimental Botany, 61, 2853-2862.

Van Dulmen, A. (2001). Pollination and phenology of flowers in the canopy of two contrasting rain forest types in Amazonia, Colombia. Plant Ecology, 153, 73-85.

Van Schaik, C. P., Terborgh, J. W., \& Wright, S. J. (1993). The phenology of tropical forests: adaptive significance and consequences for primary consumers. Annual Review of Ecology and Systematics, 24, 353-377.

Wenny, D. G., \& Levey, D. J. (1998). Directed seed dispersal by bellbirds in a tropical cloud forest. Proceedings of the National Academy of Sciences USA, 95: 6204-6207.

Wheelwright, N. T. 1983. Fruits and the ecology of the Resplendent Quetzals. Auk, 100, 286-301.

Zar, J. H. (1999). Biostatistical analysis. New Jersey: Prentice-Hall.

Zimmerman, J. K., Wright, S. J., Calderón, O., Aponte Pagán, M., \& Pat, S. (2007). Flowering and fruiting phenologies of seasonal and aseasonal neotropical forests: The role of annual changes in irradiance. Journal of Tropical Ecology, 23, 231-251. 